\title{
Pengaruh Pertumbuhan Ekonomi, Indeks Pembangunan Manusia, dan Tingkat Pengangguran Terbuka terhadap Tingkat Kemiskinan di Provinsi Jambi
}

\author{
Reki Ardian $^{1 *}$, Yulmardi ${ }^{2}$, Adi Bhakti ${ }^{3}$ \\ ${ }^{123}$ Fakultas Ekonomi dan Bisnis, Universitas Jambi, Jl. Raya Jambi - Muara Bulian KM. 15, Muaro \\ Jambi, Jambi
}

\begin{tabular}{|l|l|l|l|} 
Diterima: 20-07-2021 & Direvisi: 31-07-2021 & Disetujui: 01-08-2021 & Dipublikasi: 03-08-2021
\end{tabular}

\begin{abstract}
This study aims to determine the development and influence of economic growth, Human Development Index, open unemployment rate, and poverty level in Jambi Province. The study is a descriptive and quantitative analysis using time series data from 2000 to 2017. The study results show that during the period 2000-2017, economic growth and Human Development Index significantly affected the poverty level in Jambi Province. Meanwhile, the open unemployment rate had no significant effect on the poverty level in Jambi Province.
\end{abstract}

Keywords: economic growth, human development index, open unemployment, poverty

\begin{abstract}
Abstrak
Penelitian ini bertujuan untuk mengetahui perkembangan dan pengaruh pertumbuhan ekonomi, Indeks Pembangunan Manusia, tingkat pengangguran terbuka, dan tingkat kemiskinan di Provinsi Jambi. Metode analisis deskriptif dan kuantitatif digunakan pada data runtun waktu (time series) dari tahun 2000-2017. Hasil analisis menunjukkan bahwa selama periode tahun 2000-2017, pertumbuhan ekonomi dan indeks pembangunan manusia berpengaruh secara signifikan terhadap tingkat kemiskinan di Provinsi Jambi. Sebaliknya, tingkat pengangguran terbuka tidak memiliki pengaruh yang signifikan terhadap tingkat kemiskinan di Provinsi Jambi.
\end{abstract}

Kata kunci: pertumbuhan ekonomi, indeks pembangunan manusia, pengangguran terbuka, kemiskinan

\section{Pendahuluan}

Kemiskinan merupakan persoalan mendasar di setiap negara terutama bagi negara sedang berkembang (NSB). Sebagai salah satu negara berkembang, kemiskinan bukan merupakan masalah baru di Indonesia. Hampir semua periode pemerintah yang ada di Indonesia menempatkan masalah kemiskinan sebagai isu pembangunan.

Kemiskinan adalah keadaan saat seseorang tidak berharta, berpenghasilan rendah, dan kekurangan untuk memenuhi kebutuhan dasar minimal hidup yang layak, seperti sandang, pangan, papan, pelayanan, pendidikan, kesehatan, pelayanan air bersih, dan sanitasi (Dwijowijoto, 2004).

Menurut Sharp dalam Kuncoro (2001), ada tiga faktor penyebab kemiskinan dari sisi ekonomi. Pertama, kemiskinan muncul karena adanya ketidaksamaan pola kepemilikan sumber daya yang menimbulkan distribusi pendapatan yang timpang. Penduduk miskin hanya memiliki sumber daya terbatas dan berkualitas rendah. Kedua, kemiskinan muncul akibat perbedaan kualitas sumber daya manusia. Kualitas sumber daya manusia yang rendah

\footnotetext{
*Penulis korespondensi

Email: reki_ardian@yahoo.co.id
} 
berarti produktivitasnya rendah dan juga berarti upahnya rendah. Penyebab kualitas sumber daya manusia yang rendah adalah tingkat pendidikan yang rendah, nasib yang kurang beruntung, diskriminasi, atau keturunan. Ketiga, kemiskinan muncul karena perbedaan akses dan modal.

Selain itu kemiskinan juga dapat dikelompokkan atas bentuk-bentuk kemiskinan. Bentuk-bentuk kemiskinan ini juga dapat dipandang sebagai faktor penyebab kemiskinan (asal mula kemiskinan), yaitu (1) Kemiskinan natural, (2) Kemiskinan kultural, dan (3) Kemiskinan struktural.

Kemiskinan natural adalah kemiskinan yang terjadi memang dari awalnya telah miskin. Kelompok masyarakat ini menjadi miskin karena tidak memiliki sumber daya yang memadai baik sumberdaya alam, sumberdaya manusia maupun sumber daya pembangunan. Meskipun mereka ikut serta dalam pembangunan, imbalan pendaptan yang mereka peroleh juga relatif rendah. Kemiskinan natural ini adalah kemiskinan yang lebih disebabkan oleh faktor-faktor alamiah seperti karena cacat, sakit, usia lanjut atau karena bencana alam. (Ismanto, 1995)

Kemiskinan kultural adalah kemiskinan yang disebabkan atau mengacu pada sikap hidup seseorang atau kelompok masyarakat. Gaya hidup, kebiasaan hidup dan budaya dimana mereka merasa hidup berkecukupan dan tidak merasa kekurangan. Kelompok masyarakat ini sulit untuk diajak berpartisipasi dalam pembangunan, serta tidak mau berusaha untuk memperbaiki dan merubah tingkat kehidupannya. Ini menyebabkan tingkat pendapatan mereka rendah menurut ukuran yang dipakai secara umum. Hal ini sejalan dengan apa yang dikatakan bahwa ia miskin karena faktor budaya seperti malas, tidak disiplin, boros dan lainlainnya (Baswir, 1995)

Kemiskinan struktural adalah kemiskinan yang disebabkan oleh faktor-faktor buatan manusia seperti kebijakan ekonomi yang tidak adil, distribusi aset produksi yang tidak merata, korupsi dan kolusi serta tatanan ekonomi dunia yang cenderung menguntungkan kelompok masyarakat tertentu. Kemiskinan struktural ini pada dasarnya bersumber dai berbagai program dan kebijakan yang tidak terarah dalam pelaksanaannya. Karena pelaksanaan yang tidak terarah tersebut menyebabkan pemilikan sumber daya tidak merata, kesempatan yang tidak sama menyebabkan keikutsertaan masyarakat menjadi tidak merata pula sehingga menimbulkan struktur masyarakat yang timpang. Hal ini disebut "accidental poverty", yaitu kemiskinan karena dampak dari suatu kebijaksanaan tertentu yang menyebabkan menurunnya tingkat kesejahteraan masyarakat (Baswir, 1995)

Provinsi Jambi merupakan salah satu provinsi di Indonesia yang masih menghadapi banyak persoalan sosial ekonomi, seperti angka kemiskinan yang tinggi. Oleh sebab itu, kemiskinan menjadi tanggung jawab bersama terutama bagi pemerintah Provinsi Jambi sebagai penyangga proses perbaikan kehidupan masyarakat dalam pemberantasan kemiskinan. Variabel kemiskinan menjadi momok tersendiri dalam permasalahan pokok kependudukan pada proses pembangunan ekonomi di setiap wilayah, seperti halnya kesehatan, pengangguran, dan variabel penting lainnya. Kemiskinan merupakan bagian dari lingkaran setan pada permasalahan ekonomi khususnya di Provinsi Jambi.

Berdasarkan data dari Badan Pusat Statistik (BPS), tingkat kemiskinan di Provinsi Jambi mengalami fluktuasi setiap tahunnya dari tahun 2013-2017. Antara tahun 2013 dan 2015, angkanya mengalami fluktuasi, yaitu 8,41 persen pada tahun $2013,8,39$ persen pada tahun 2014, dan 8,86 persen pada tahun 2015. Tingkat kemiskinan pada tahun 2016 dan 2017 mengalami penurunan masing-masing sebesar 8,41 persen dan 8,19 persen (BPS, 2018).

Pertumbuhan ekonomi atau peningkatan PDRB (Produk Domestik Regional Bruto) merupakan salah satu ukuran dan indikasi penting untuk menilai keberhasilan pembangunan ekonomi suatu daerah ditinjau dari sisi ekonominya. Pertumbuhan ekonomi merupakan kunci penurunan kemiskinan di setiap daerah. Adanya peningkatan dalam pertumbuhan ekonomi 
suatu daerah menandai adanya peningkatan kesejahteraan masyarakat sehingga kemiskinan menurun.

Data yang dipublikasikan oleh BPS Provinsi Jambi menunjukkan bahwa pertumbuhan ekonomi Provinsi Jambi mengalami fluktuasi dari tahun 2013-2017. Pada tahun 2013-2014 pertumbuhan ekonomi mengalami peningkatan, yaitu 7,07 persen (2013) dan 7,76 persen (2014). Namun, pada tiga tahun terakhir (2015-2017), terjadi penurunan, yaitu 4,21 persen (2015), 4,37 persen (2016), dan 4,64 persen (2017) (BPS, 2019a).

Salah satu indikator untuk melihat keberhasilan pembangunan ekonomi suatu daerah adalah Indeks Pembangunan Manusia (IPM). IPM merupakan tolak ukur pembangunan suatu daerah yang berkorelasi negatif terhadap kemiskinan di daerah tersebut. Jika suatu daerah memiliki nilai IPM yang tinggi, idealnya kualitas hidup masyarakat juga tinggi atau dapat dikatakan bahwa jika nilai IPM tinggi, maka seharusnya jumlah penduduk miskin akan berkurang.

Berdasarkan data yang diperoleh dari BPS, IPM Provinsi Jambi dari tahun 2013 2017 menunjukan peningkatan setiap tahunnya. Pada tahun 2013, IPM Provinsi Jambi sebesar 74,35 persen. Setelah itu, angka IPM terus mengalami peningkatan dari tahun ke tahun, dan pada tahun 2017, IPM Provinsi Jambi sebesar 76,53 persen (BPS, 2020a).

Menurut Sukirno (2000), pengangguran akan menimbulkan efek mengurangi pendapatan masyarakat yang akan mengurangi tingkat kemakmuran yang telah tercapai. Tingkat kemakmuran yang semakin menurun akan menimbulkan masalah lain, yaitu kemiskinan.

Berdasarkan data yang dipublikasikan oleh BPS, Tingkat Pengangguran Terbuka (TPT) Provinsi Jambi dari tahun 2013-2017 mengalami kenaikan dan penurunan. Pada tahun 2013, angka TPT sebesar 4,84 persen dan pada tahun 2014, TPT mengalami peningkatan mencapai 5,08 persen. Pada tahun 2015-2017, tingkat pengangguran terbuka kembali mengalami penurunan setiap tahunnya, yaitu 4,34 persen (2015), 4,00 persen (2016), dan 3,87 persen (2017) (BPS, 2020b).

Berdasarkan uraian tersebut, tujuan dari penelitian ini adalah untuk menganalisis: 1) Perkembangan pertumbuhan ekonomi, Indeks Pembangunan Manusia, tingkat pengangguran terbuka dan tingkat kemiskinan di Provinsi Jambi; dan 2) Pengaruh pertumbuhan ekonomi, Indeks Pembangunan Manusia dan tingkat pengangguran terbuka terhadap tingkat kemiskinan di Provinsi Jambi.

\section{Metode}

Jenis data yang digunakan dalam penelitian ini adalah data sekunder berupa data time series dari tahun 2000-2017 yang diperoleh dari Badan Pusat Statistik (BPS) Provinsi Jambi. Data mencakup pertumbuhan ekonomi, indeks pembangunan manusia (IPM), tingkat pengangguran terbuka (TPT) dan tingkat kemiskinan di Provinsi Jambi.

Analisis data dilakukan secara deskriptif dan model persamaan regresi linier berganda dengan model sebagai berikut:

$$
\begin{array}{ll}
Y=\beta_{0}+\beta_{1} P E+\beta_{2} I P M+\beta_{3} T P T+e \\
\text { Keterangan: } & \\
\text { Y } & =\text { Tingkat kemiskinan } \\
\text { PE } & =\text { Pertumbuhan Ekonomi } \\
\text { IPM } & =\text { Indeks Pembangunan Manusia } \\
\text { TPT } & =\text { Tingkat Pengangguran Terbuka } \\
\beta_{0} & =\text { Konstanta Regresi } \\
\beta_{1} \beta_{2} \beta_{3} & =\text { Koefisien Regresi masing-masing variabel } \\
e & =\text { Kesalahan Pengganggu }
\end{array}
$$




\section{Hasil dan Pembahasan}

\section{Pertumbuhan Ekonomi}

Menurut Sukirno (2007), pertumbuhan ekonomi adalah proses kenaikan keluaran (output) perkapita yang terus menerus dalam jangka panjang. Secara umum, pertumbuhan ekonomi diartikan sebagai peningkatan dari suatu perekonomian dalam memproduksi barangbarang dan jasa-jasa.

Rata-rata pertumbuhan ekonomi di Provinsi Jambi periode 2000-2017 sebesar 6,12 persen. Pertumbuhan ekonomi di Provinsi Jambi berada pada kondisi fluktuatif dari tahun 2000-2017. Rincian data dapat dilihat pada Tabel 1.

Tabel 1. Pertumbuhan ekonomi di Provinsi Jambi Tahun 2000-2017

\begin{tabular}{ccc}
\hline Tahun & PDRB ADHK (Juta Rupiah) & $\begin{array}{c}\text { Pertumbuhan ekonomi } \\
(\%)\end{array}$ \\
\hline 2000 & 9.569 .242 & 5,33 \\
2001 & 10.205 .590 & 5,87 \\
2002 & 10.803 .423 & 5,86 \\
2003 & 11.343 .280 & 5,00 \\
2004 & 11.953 .885 & 5,38 \\
2005 & 12.619 .971 & 5,57 \\
2006 & 13.363 .621 & 5,89 \\
2007 & 14.275 .161 & 6,82 \\
2008 & 15.297 .771 & 7,16 \\
2009 & 16.272 .259 & 6,39 \\
2010 & 17.471 .686 & 7,35 \\
2011 & 18.963 .518 & 8,54 \\
2012 & 20.373 .533 & 7,03 \\
2013 & 21.979 .277 & 7,07 \\
2014 & 23.309 .000 & 7,76 \\
2015 & 25.678 .445 & 4,21 \\
2016 & 27.309 .654 & 4,37 \\
2017 & 28.101 .342 & 4,64 \\
\hline Rata-rata & & 6,12 \\
\hline
\end{tabular}

Sumber: BPS, 2019

Berdasarkan Tabel 1, pertumbuhan ekonomi di Provinsi Jambi tertinggi terjadi pada tahun 2011, yaitu sebesar 8,54 persen. Hal ini menunjukkan bahwa sektor-sektor ekonomi di Provinsi Jambi membaik dan infrastruktur yang memadai sejak tahun-tahun sebelumnya membuat perekonomian semakin baik. Sebaliknya, pertumbuhan ekonomi terendah terjadi pada tahun 2005, yaitu sebesar 4,21 persen. Hal ini diperkirakan terjadi karena masih lemahnya ekonomi global dan tren penurunan harga komoditas unggulan, seperti minyak mentah, batu bara, kelapa sawit, dan karet.

\section{Indeks Pembangunan Manusia}

Menurut BPS (2009), Indeks Pembangunan Manusia (IPM) merupakan capaian pembangunan berbasis sejumlah komponen dasar kualitas hidup. IPM merupakan indikator strategis yang banyak digunakan untuk melihat upaya dan kinerja program pembangunan secara menyeluruh di suatu wilayah. Dalam hal ini, IPM dipandang sebagai gambaran dari hasil program pembangunan yang telah dilakukan beberapa tahun sebelumnya. Kemajuan program pembangunan dalam suatu periode juga dapat diukur dan ditunjukkan oleh besaran IPM pada awal dan akhir periode tersebut. IPM merupakan ukuran untuk melihat kinerja pembangunan wilayah yang mempunyai dimensi yang sangat luas karena memperlihatkan kualitas penduduk suatu wilayah dalam hal harapan hidup, kecerdasan, dan standar hidup layak.

Keberhasilan pembangunan manusia dapat dinilai dari seberapa besar permasalahan yang dapat diatasi, terutama permasalahan yang paling mendasar. Permasalahan- 
permasalahan itu dapat berupa masalah kemiskinan, pengangguran, pendidikan yang tidak menyeluruh, dan masalah keberhasilan pembangunan manusia dari aspek ekonomi lainnya. Tercapainya tujuan pembangunan yang tercermin pada IPM sangat tergantung pemerintah sebagai penyedia sarana penunjang (Harliyani \& Haryadi, 2016).

Indeks Pembangunan Manusia di Provinsi Jambi periode 2000-2017 memiliki ratarata perkembangan sebesar 0,71 persen dan mengalami peningkatan setiap tahunnya. Rincian data dapat dilihat pada Tabel 2 .

Tabel 2. Indeks Pembangunan Manusia di Provinsi Jambi Tahun 2000-2017

\begin{tabular}{ccc}
\hline Tahun & Indeks Pembangunan Manusia (\%) & Perkembangan (\%) \\
\hline 2000 & 67,78 & - \\
2001 & 67,95 & 0,25 \\
2002 & 68,80 & 1,25 \\
2003 & 69,75 & 1,38 \\
2004 & 70,10 & 0,50 \\
2005 & 71,00 & 1,28 \\
2006 & 71,30 & 0,42 \\
2007 & 71,46 & 0,22 \\
2008 & 71,99 & 0,74 \\
2009 & 72,45 & 0,63 \\
2010 & 72,74 & 0,40 \\
2011 & 73,30 & 0,76 \\
2012 & 73,75 & 0,61 \\
2013 & 74,35 & 0,81 \\
2014 & 75,43 & 1,45 \\
2015 & 76,01 & 0,76 \\
2016 & 76,21 & 0,26 \\
2017 & 76,53 & 0,41 \\
\hline Rata-rata & $\mathbf{7 2 , 2 7}$ & $\mathbf{0 , 7 1}$ \\
\hline
\end{tabular}

Sumber: BPS, 2020a

Berdasarkan Tabel 2, Indeks Pembangunan Manusia di Provinsi Jambi memiliki perkembangan tertinggi pada tahun 2014 sebesar 1,45 persen. Hal ini menunjukkan bahwa mulai terjadi perbaikan di sektor pendidikan, kesehatan, serta meningkatnya daya beli masyarakat. Sebaliknya, perkembangan terendah terjadi pada tahun 2007 sebesar 0,22 persen.

\section{Tingkat Pengangguran Terbuka}

Tingkat pengangguran terbuka adalah persentase jumlah pengangguran terhadap jumlah angkatan kerja. Angkatan Kerja adalah penduduk usia kerja (15 tahun ke atas) yang bekerja atau punya pekerjaan namun sementara tidak bekerja, dan penggangguran.Pengangguran yaitu: (1) penduduk yang aktif mencari pekerjaan, (2) penduduk yang sedang mempersiapkan usaha/pekerjaan baru, (3) penduduk yang tidak mencari pekerjaan karena merasa tidak mungkin mendapat pekerjaan, (4) kelompok penduduk yang tidak aktif mencari pekerjaan dengan alasan sudah mempunyai pekerjaan tetapi belum mulai bekerja.

Menurut Kuncoro (2010), pengangguran terbuka adalah masalah makro ekonomi yang mempengaruhi manusia secara langsung dan merupakan yang paling berat. Kehilangan pekerjaan dapat dianggap sebagai penurunan standar kehidupan dan rekanan psikologis. Jadi, tidaklah mengejutkan jika pengangguran terbuka menjadi topik yang sering dibicarakan dalam perdebatan politik, dan para politisi sering mengklaim bahwa kebijakan yang mereka tawarkan akan membantu menciptakan lapangan kerja.

Tingkat pengangguran terbuka di Provinsi Jambi periode 2000-2017 memiliki ratarata perkembangan sebesar 3,83 persen dan mengalami fluktuasi. Rincian data dapat dilihat pada Tabel 3. 
Tabel 3. Tingkat pengangguran terbuka di Provinsi Jambi Tahun 2000-2017

\begin{tabular}{ccc}
\hline Tahun & Tingkat Pengangguran Terbuka (\%) & Perkembangan (\%) \\
\hline 2000 & 3,68 & 5,24 \\
2001 & 5,61 & 3,03 \\
2002 & 5,78 & 1,24 \\
2003 & 6,50 & $-7,07$ \\
2004 & 6,04 & 7,78 \\
2006 & 10,74 & $-3,83$ \\
2007 & 6,62 & $-6,04$ \\
2008 & 6,22 & $-1,72$ \\
2009 & 5,15 & 7,57 \\
2010 & 5,54 & $-8,30$ \\
2011 & 5,08 & $-2,08$ \\
2012 & 4,02 & $-1,99$ \\
2013 & 3,22 & 5,03 \\
2014 & 4,84 & 4,95 \\
2015 & 5,08 & $-1,45$ \\
2016 & 4,34 & $-7,83$ \\
2017 & 4,00 & $-3,25$ \\
\hline Rata-rata & 3,87 & 3,83 \\
\hline
\end{tabular}

Sumber: BPS, 2020b

Berdasarkan data pada Tabel 3, Tingkat Pengangguran Terbuka di Provinsi Jambi periode 2000-2017 memiliki perkembangan tertinggi pada tahun 2005 sebesar 7,78 persen. Inflasi yang tinggi pada tahun tersebut berpengaruh langsung terhadap pengangguran. Selanjutnya, tingkat pengangguran terbuka pada tahun 2010 mengalami penurunan yang cukup drastis dari tahun sebelumnya, yaitu sebesar 5,08 persen dan diikuti dengan perkembangan yang menurun pula sebesar $-8,30$ persen. Hal ini mungkin terjadi karena kestabilan lapangan pekerjaan tahun tersebut.

\section{Tingkat Kemiskinan}

Tingkat kemiskinan dapat diartikan sebagai persentase penduduk di bawah garis kemiskinan. Garis kemiskinan merupakan jumlah rupiah minimum yang dibutuhkan untuk memenuhi kebutuhan pokok minimum makanan yang setara dengan 2100 kilokalori per kapita per hari dan kebutuhan pokok bukan makanan. Penduduk yang memiliki rata-rata pengeluaran konsumsi per kapita per bulan di bawah garis kemiskinan dikategorikan sebagai penduduk miskin

Kemiskinan adalah masalah yang dihadapi oleh seluruh negara, terutama di negara berkembang. Masalah kemiskinan merupakan suatu permasalahan yang kompleks, baik dilihat dari penyebabnya maupun dampaknya. Kemiskinan bersifat multidimensional dan menyangkut seluruh dimensi kebutuhan manusia yang beragam. Selain itu, dimensi kebutuhan manusia yang beraneka ragam itu pun saling terkait satu dengan yang lainnya (Suparmoko, 2002).

Todaro \& Smith (2003) mengungkapkan generalisasi yang paling tepat tentang kemiskinan, yakni mereka yang ditempatkan di daerah pedesaan secara tidak seimbang, dan terutama sekali bagi mereka yang bekerja di bidang pertanian atau kegiatan-kegiatan usaha bersama. Berdasarkan definisi tersebut, kemiskinan merupakan kondisi saat seseorang tidak dapat menikmati segala macam pilihan dan kesempatan dalam pemenuhan kebutuhan dasarnya, seperti tidak dapat memenuhi kebutuhan kesehatan, standar hidup layak, kebebasan, harga diri, dan rasa dihormati seperti orang lain.

Tingkat kemiskinan di Provinsi Jambi selama tahun 2000-2017 memiliki rata-rata perkembangan sebesar $-2,91$ persen dan menunjukkan peningkatan serta penurunan yang berbeda-beda di tiap tahunnya. Rincian data dapat dilihat pada Tabel 4. 
Tabel 4. Tingkat kemiskinan di Provinsi Jambi Tahun 2000-2017

\begin{tabular}{ccc}
\hline Tahun & Tingkat Kemiskinan (\%) & Perkembangan (\%) \\
\hline 2000 & 13,75 & - \\
2001 & 13,35 & $-2,90$ \\
2002 & 13,18 & $-1,27$ \\
2003 & 12,74 & $-3,33$ \\
2004 & 12,45 & $-2,27$ \\
2005 & 11,88 & $-4,57$ \\
2006 & 11,37 & $-4,29$ \\
2007 & 10,27 & $-9,67$ \\
2008 & 9,28 & $-9,63$ \\
2009 & 8,55 & $-7,86$ \\
2010 & 8,40 & $-1,75$ \\
2011 & 7,90 & $-5,95$ \\
2012 & 8,28 & 4,80 \\
2013 & 8,41 & 1,57 \\
2014 & 8,39 & $-0,23$ \\
2015 & 8,86 & 5,60 \\
2016 & 8,41 & 5.07 \\
2017 & 8,19 & $-2,61$ \\
Rata-rata & $\mathbf{1 0 , 2 0}$ & $\mathbf{- 2 , 9 1}$
\end{tabular}

Berdasarkan Tabel 4, tingkat kemiskinan di Provinsi Jambi periode tahun 2000-2017 mengalami fluktuasi dan perkembangan tertinggi terjadi pada tahun 2015, yaitu sebesar 5,60 persen. Hal ini menunjukkan bahwa perekonomian di Provinsi Jambi semakin memburuk dan berarti Pemerintah Provinsi Jambi belum sepenuhnya berhasil dalam mengatasi masalah kemiskinan. Sebaliknya, perkembangan terendah dan penurunan terjadi pada tahun 2007 sebesar $-9,67$ persen.

\section{Pengaruh Pertumbuhan Ekonomi, Indeks Pembangunan Manusia, Tingkat} Pengangguran Terbuka terhadap Tingkat Kemiskinan di Provinsi Jambi

Pengujian data dalam penelitian ini menggunakan regresi linear berganda yang bertujuan untuk mengetahui pengaruh pertumbuhan ekonomi, indeks pembangunan manusia dan tingkat pengangguran terbuka terhadap tingkat kemiskinan di Provinsi Jambi.

\section{Uji asumsi klasik}

\section{Uji multikolinearitas}

Multikolinearitas merupakan salah satu model asumsi klasik yang melihat hubungan antara sesama variabel bebas. Pengujian multikolinearitas menggunakan uji variance inflation factors (VIF).

Tabel 5. Hasil uji multikolinearitas

\begin{tabular}{cccc}
\hline & $\begin{array}{c}\text { Coefficient } \\
\text { Variance }\end{array}$ & $\begin{array}{c}\text { Uncentered } \\
\text { VIF }\end{array}$ & $\begin{array}{c}\text { Centered } \\
\text { VIF }\end{array}$ \\
\hline Cariable & 18.75133 & 968.8975 & NA \\
PE & 0.013934 & 28.01573 & 1.009833 \\
IPM & $3.12 \mathrm{E}-07$ & 842.6506 & 1.169659 \\
TPT & 0.008551 & 13.83465 & 1.180263 \\
\hline
\end{tabular}

Dari Tabel 5, terlihat bahwa nilai VIF lebih kecil dari 10, maka tidak ada gejala multikolinearitas pada penelitian ini. 


\section{Uji heteroskedastisitas}

Pengujian heteroskedastisitas digunakan untuk mengetahui ada atau tidaknya penyimpangan asumsi klasik. Pengujian heteroskedastisitas melihat ketidaksamaan varian dari residual satu ke pengamatan model lainnya. Hasil uji heteroskedastisitas pada Tabel 6.

Tabel 6. Uji heteroskedastisitas

\begin{tabular}{lll}
\hline F-statistic & 0.805873 Prob. F(9,8) & 0.6251 \\
Obs $^{*}$-squared & 8.559148 Prob. Chi-Square(9) & 0.4789 \\
Scaled explained SS & 11.18102 Prob. Chi-Square(9) & 0.2635 \\
\hline
\end{tabular}

Dari data di atas, probabilitas Chi-Square lebih besar dari nilai $\alpha$ yang dipilih, yaitu $0,4789>0,05$ tidak ditemukan masalah heteroskedastisitas atau terbebas dari gejala heteroskedastisitas.

\section{Uji autokorelasi}

Uji autokorelasi bertujuan untuk menguji keberadaan korelasi atau hubungan antara kesalahan pengganggu pada periode $\mathrm{t}$ dengan kesalahan pengganggu pada periode $\mathrm{t}-1$ dalam model regresi linier.

Tabel 7. Hasil uji autokorelasi

\begin{tabular}{lll}
\hline F-statistic & 2.294730 Prob. F(2,12) & 0.1432 \\
Obs*R-squared & 4.979685 Prob. Chi-Square(2) & 0.0829 \\
\hline
\end{tabular}

Berdasarkan Tabel 7, hasil uji autokorelasi dengan metode LM (Lagrange-Multiplier) menunjukkan nilai probabilitas Chi-Square sebesar 0,0829>0,05 yang berarti tidak ditemukan masalah autokorelasi.

\section{Uji normalitas}

Untuk menguji data berdistribusi normal atau tidak, maka dilakukan analisis dengan menggunakan metode Jarque Bera. Gambar 1 menunjukkan hasil uji normalitas.

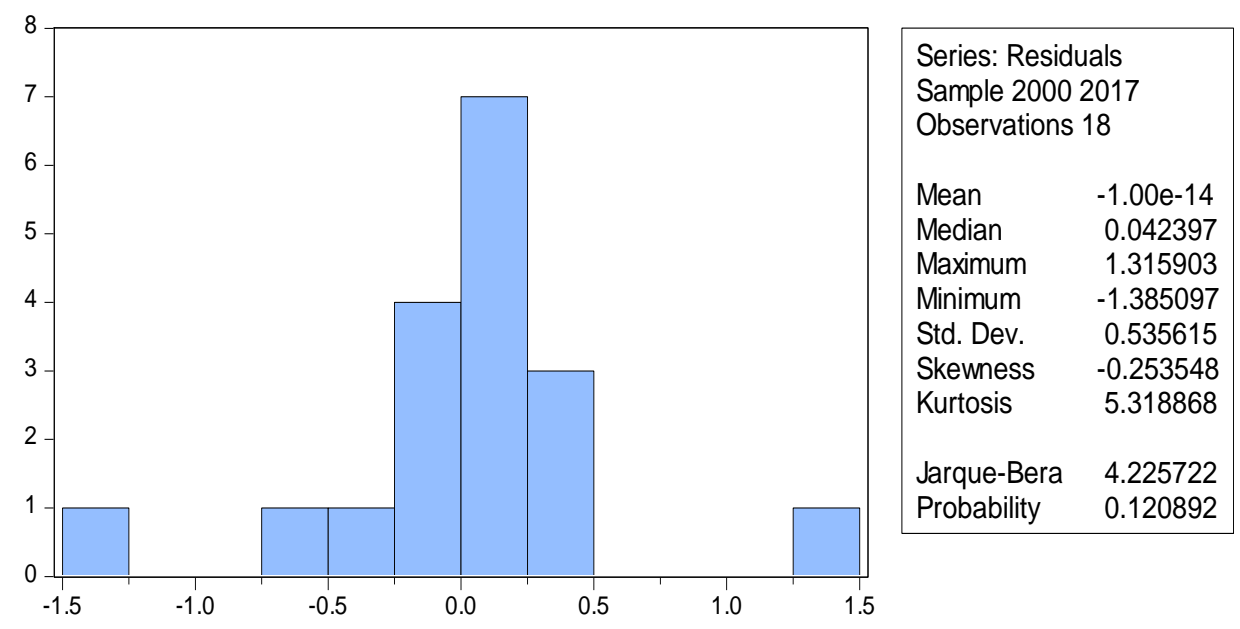

Gambar 1. Hasil uji normalitas

Dari Gambar 1 di atas, nilai probabilitas yang diperoleh sebesar 0,120892 >0,05 (lebih besar dari $\alpha=0,05$ ), sehingga model berdistribusi normal dan terbebas dari gejala normalitas.

\section{Uji hipotesis}

\section{Uji F}

Pengujian secara simultan (Uji F) digunakan untuk melihat pengaruh variabel pertumbuhan ekonomi, indeks pembangunan manusia, tingkat pengangguran terbuka yang 
dimasukan dalam model dan signifikansinya terhadap tingkat kemiskinan di Provinsi Jambi. Dengan membandingkan Prob(F-statistik) terhadap nilai a $5 \%=0,05$, pengaruh variabel pertumbuhan ekonomi, indeks pembangunan manusia, dan tingkat pengangguran terbuka terhadap tingkat kemiskinan di Provinsi Jambi dapat dilihat.

Tabel 5. Hasil Uji F Statistik

\begin{tabular}{lrll}
\hline R-squared & 0.937138 & Mean dependent var & 10.19667 \\
Adjusted R-squared & 0.923668 & S.D. dependent var & 2.136286 \\
S.E. of regression & 0.590219 & Akaike info criterion & 1.976485 \\
Sum squared resid & 4.877022 & Schwarz criterion & 2.174345 \\
Log likelihood & -13.78836 & Hannan-Quinn criter. & 2.003767 \\
F-statistic & 69.57022 & Durbin-Watson stat & 1.181033 \\
Prob(F-statistic) & 0.000000 & & \\
\hline
\end{tabular}

Berdasarkan hasil uji F, nilai Prob(F-statistik) sebesar 0,00000 dan lebih kecil dari tingkat signifikansi sebesar $5 \%=0,05$, sehingga $\mathrm{H}_{0}$ ditolak. Hal ini menunjukkan bahwa variabel pertumbuhan ekonomi, indeks pembangunan manusia, tingkat pengangguran terbuka secara bersama-sama (simultan) berpengaruh signifikan terhadap tingkat kemiskinan di Provinsi Jambi.

\section{Koefisien determinasi $\left(\boldsymbol{R}^{2}\right)$}

Koefisien determinasi digunakan untuk melihat seberapa besar tingkat pengaruh variabel bebas, yaitu variabel pertumbuhan ekonomi, Indeks Pembangunan Manusia, dan tingkat pengangguran terbuka terhadap variabel terikat, yaitu tingkat kemiskinan.

Hasil pengujian menunjukkan nilai koefisien determinasi $\left(R^{2}\right)$ sebesar 0,937138 . Ternyata pertumbuhan ekonomi, indeks pembangunan manusia, dan tingkat pengangguran terbuka mampu menjelaskan tingkat kemiskinan sebesar 93,71 persen dan sisanya 6,29 persen variabel lainnya yang tidak termasuk dalam penelitian ini.

\section{Uji $t$}

Uji statistik t pada dasarnya digunakan untuk menunjukan besar pengaruh variabel bebas secara individual dalam menerangkan variasi variabel terikat dengan (Ghozali, 2016): . Hasil uji t statistik diberikan sebagai berikut:

Tabel 6. Hasil Uji t Statistik

\begin{tabular}{crrrr}
\hline Variable & Coefficient & Std. Error & t-Statistic & Prob. \\
\hline C & 61.03809 & 4.330280 & 14.09564 & 0.0000 \\
PE & -0.619420 & 0.118043 & -5.247413 & 0.0001 \\
IPM & -0.006589 & 0.000558 & -11.79963 & 0.0000 \\
TPT & 0.106474 & 0.092472 & 1.151418 & 0.2688 \\
\hline
\end{tabular}

\section{Pengaruh Pertumbuhan Ekonomi terhadap Tingkat Kemiskinan}

Dalam pengujian koefisien regresi menggunakan $\alpha=5 \%(0,05)$, nilai t hitung variabel pertumbuhan ekonomi sebesar -5,247413 dengan probabilitas variabel pertumbuhan ekonomi sebesar 0,0001 atau lebih kecil dari $\alpha=0,05(0,0001<0,05)$, maka $\mathrm{H}_{0}$ ditolak dan $\mathrm{H}_{\mathrm{a}}$ diterima. Hal ini berarti variabel pertumbuhan ekonomi secara individual berpengaruh signifikan terhadap tingkat kemiskinan di Provinsi Jambi.

Pengaruh negatif yang signifikan antara pertumbuhan ekonomi dengan tingkat kemisknan ini sejalan dengan temuan Siregar dan Wahyuni (2016) pada data tingkat nasional (Indonesia), dan penelitian Safuridar (2017) di Kabupaten Aceh Timur. Namun demikian temuan penelitian ini berbeda dengan temuan Pananrangi (2012) di Sumatera Selatan dan Prasetyo (2020) di Kediri yang menunjukkan tidak berdampaknya pertumbuhan ekonomi terhadap kemiskinan. 


\section{Pengaruh Indeks Pembangunan Manusia terhadap Tingkat Kemiskinan}

Dengan pengujian koefisien regresi menggunakan $\alpha=5 \%(0,05)$, nilai $\mathrm{t}$ hitung variabel Indeks Pembangunan Manusia sebesar -11,7993 dengan probabilitas variabel Indeks Pembangunan Manusia sebesar 0,0000 atau lebih kecil dari $\alpha=0,05(0,0000<0,05)$, maka $\mathrm{H}_{0}$ ditolak dan $\mathrm{H}_{\mathrm{a}}$ diterima. Hal ini menunjukkan bahwa variabel Indeks Pembangunan Manusia secara individual berpengaruh signifikan terhadap tingkat kemiskinan di Provinsi Jambi. Temuan penelitian ini sejalan dengan temuan penelitian Syaifullah \& Gandasari (2016) di Provinsi Banten dan Utami (2020) di Aceh.

\section{Pengaruh Tingkat Pengangguran Terbuka terhadap Tingkat Kemiskinan}

Dengan pengujian koefisien regresi menggunakan $\alpha=5 \%(0,05)$ variabel tingkat pengangguran terbuka, nilai t hitung sebesar 1,151418 dengan probabilitas variabel tingkat pengangguran terbuka sebesar 0,2688 atau lebih besar dari $\alpha=0,05(0,2688>0,05)$, maka $\mathrm{H}_{0}$ diterima dan $\mathrm{H}_{\mathrm{a}}$ ditolak. Hal ini berarti variabel tingkat pengangguran terbuka secara individual tidak berpengaruh signifikan terhadap tingkat kemiskinan di Provinsi Jambi.

Tidak signifikannya pengaruh tingkat pengangguran terbuka terhadap kemiskinan diduga disebabkan banyaknya pengangguran tersembunyi (mereka yang bekerja dengan jam kerja rendah) yang tercatat sebagai penduduk bekerja. Hal ini umumnya terlihat pada rumah tangga pertanian perdesaan.

Fakta ini dibuktikan oleh Kakwani dan Son (2006) berdasarkan penelitian dengan di Brazil yang menggunakan dua pendekatan, yaitu data tingkat pengangguran dengan ukuran pengangguran konvensional dan data pengangguran dengan ukuran pengangguran yang dimodifikasi. Pengangguran dengan ukuran konvensional menunjukkan hasil tidak signifikannya hubungan antara pengangguran dan kemiskinan. Dengan memodifikasi pengukuran tingkat pengangguran konvensional mereka menemukan bahwa korelasi antara tingkat pengangguran dan kemiskinan menjadi signifikan

Temuan penelitian ini sejalan dengan temuan Syaifullah dan Gandasari (2016) di Provinsi Banten. Temuan senada juga ditemukan pada penelitian Yacoub (2012) di Provinsi Kalimantan Bara. Namun demikian temuan ini berbeda dengan temuan Utami (2020) di Aceh dan Deffrinica (2017) di Kabupaten Bengkayang, yang menunjukkan adanya pengaruh negatif pengangguran terhadap kemiskinan.

\section{Kesimpulan}

\section{Kesimpulan dan Saran}

Rata-rata untuk perkembangan tingkat kemiskinan, pertumbuhan ekonomi, Indeks Pembangunan Manusia, dan tingkat pengangguran terbuka setiap tahunnya secara berturutturut adalah -2,91 persen, 6,12 persen, 0,71 persen, dan 3,83 persen. Pertumbuhan Ekonomi dan Indeks Pembangunan Manusia berpengaruh signifikan terhadap tingkat kemiskinan. Namun demikian, tingkat pengangguran terbuka tidak menunjukkan pengaruh yang signifikan terhadap tingkat kemiskinan di Provinsi Jambi.

\section{Saran}

Setelah mengetahui bahwa rata-rata tingkat kemiskinan di Provinsi Jambi masih tergolong sangat tinggi, Pemerintah Provinsi Jambi disarankan untuk mendorong pertumbuhan ekonomi dan meningkatkan kualitas sumber daya manusia dengan cara salah satunya, yaitu meningkatkan kualitas pendidikan, kesehatan, dan pendapatan. Pemerintah juga harus lebih memperhatikan ketersediaan lapangan kerja untuk mengurangi angka pengangguran. Untuk penelitian selanjutnya dengan topik tingkat kemiskinan, disarankan untuk melakukan dengan kajian lebih lanjut dengan memasukan variabel lain seperti kesehatan, pendidikan, pendapatan, dan belanja daerah. Selain itu, peneliti dapat 
memperpanjang tahun penelitian dan menggunakan metode analisis yang lebih akurat agar mendapatkan hasil yang lebih mendekati fenomena sesungguhnya.

\section{Daftar Pustaka}

Baswir. (1995). Ekonomi pembangunan dan perencanaan. Rajawali Press.

BPS. (2018). Analisis kondisi kemiskinan Provinsi Jambi 2017. Badan Pusat Statistik

Provinsi Jambi.

https://jambi.bps.go.id/publication/2018/04/19/c991c6ee0e1f24188b92f203/analisis-

kondisi-kemiskinan-provinsi-jambi-2017.html

BPS. (2019). Analisis pertumbuhan ekonomi Provinsi Jambi Tahun 2018. Badan Pusat

Statistik Provinsi Jambi.

https://jambi.bps.go.id/publication/2019/11/22/ada96ef82f501f048cc4c8ac/analisis-

pertumbuhan-ekonomi--provinsi-jambi-2018.html

BPS. (2020a). Indeks pembangunan manusia Provinsi Jambi 2019. Badan Pusat Statistik

Provinsi Jambi.

https://jambi.bps.go.id/publication/2020/07/13/ea9787eb3eb882c33d03cd7b/indeks-

pembangunan-manusia-provinsi-jambi-2019.html

BPS. (2020b). Analisis situasi ketenagakerjaan Provinsi Jambi 2019. Badan Pusat Statistik. https://jambi.bps.go.id/publication/2020/09/15/d43d92a7cb823f09ab4df6f6/analisissituasi-ketenagakerjaan-provinsi-jambi-2019.html

Deffrinica, D. (2017). Pengaruh tingkat pengangguran terhadap kemiskinan di Kabupaten Bengkayang. JURKAMI, 2(1), 37-47. https://doi.org/10.31932/jpe.v2i1.462

Dwijowijoto, R. N. (2004). Kebijakan publik formulasi, implementasi, dan evaluasi. Elex Media Komputindo.

Ghozali, I. (2016). Aplikasi analisis multivariate dengan program IBM SPSS 23 (Edisi ke-8). Badan Penerbit Universitas Diponegoro.

Harliyani, E. M., \& Haryadi, H. (2016). Pengaruh kinerja keuangan pemerintah daerah terhadap indeks pembangunan manusia di Provinsi Jambi. Jurnal Perspektif Pembiayaan Dan Pembangunan Daerah, 3(3), 129-140. https://doi.org/10.22437/ppd.v3i3.3514

Ismanto, I.G.N. (1995). Kemiskinan di Indonesia dan program IDT. Centre for Strategic and International Studies.

Kuncoro, M. (2001). Metode kuantitatif teori dan aplikasi untuk bisnis dan ekonomi. AMP YKPN.

Kuncoro, M. (2010). Masalah, kebijakan, dan politik ekonomika pembangunan. Erlangga.

Kakwani, N., \& Son H.H. (Juni 2006). Pro-poor growth: The Asian experience [WIDER Research Paper, No. 2006/56). https://www.econstor.eu/handle/10419/63301

Safuridar, S. (2017). Pengaruh pertumbuhan ekonomi terhadap kemiskinan di Kabupaten Aceh Timur. Ihtiyath: Jurnal Manajemen Keuangan Syariah, 1(1). https://doi.org/10.32505/ihtiyath.v1i1.674

Siregar, H., \& Wahyuni, D. (2008). Dampak pertumbuhan ekonomi terhadap penurunan jumlah penduduk miskin. Jurnal Ilmiah. https://pse.litbang.pertanian.go.id/ind/pdffiles/PROS_2008_MAK3.pdf

Prasetyo, N. (2020). Analisis pengaruh pertumbuhan ekonomi terhadap tingkat kemiskinan di Kabupaten Kediri. RISK: Jurnal Riset Bisnis dan Ekonomi, 1(2), 55-71. http://dx.doi.org/10.30737/risk.v1i2.1335

Sukirno, S. (2000). Makroekonomi modern. RajaGrafindo Persada.

Sukirno, S. (2006). Makroekonomi modern. RajaGrafindo Persada. 
Suparmoko, M. (2002). Ekonomi publik untuk keuangan dan pembangunan daerah. Andi. Syaifullah, S., \& Gandasari, T.R. (2016). Pengaruh indeks pembangunan manusia dan pengangguran terhadap kemiskinan di Provinsi Banten. Jurnal Ekonomi-Qu, 6(2). http://dx.doi.org/10.35448/jequ.v6i2.4345

Todaro, M. P., \& Smith, S. C. (2003). Pembangunan ekonomi di dunia ketiga (Edisi ke-8). Erlangga.

Utami, F.P. (2020). Pengaruh indeks pembangunan manusia (IPM), kemiskinan, pengangguran terhadap pertumbuhan ekonomi di Provinsi Aceh. Jurnal Samudra Ekonomika, 4(2), 101-113. https://doi.org/10.33059/jse.v4i2.2303

Widarjono, A. (2009). Ekonometrika pengantar dan aplikasinya (Edisi ke-3). Ekonisia.

Yacoub, Y. (2012). Pengaruh tingkat pengangguran terhadap tingkat kemiskinan

Kabupaten/Kota di Provinsi Kalimantan Barat. Kumpulan e-Journal Eksos, 8(3), 176185. http://repository.polnep.ac.id/xmlui/handle/123456789/63

(C) 2021 oleh penulis. Pemegang Lisensi JEA, Indonesia. Artikel ini merupakan artikel akses terbuka yang didistribusikan di bawah syarat dan ketentuan Lisensi Atribusi Creative Commons (CC BY-SA) (http://creativecommons.org/licenses/by/4.0/) 